BULLETIN Bulletin hispanique

HISPANIQUE Université Michel de Montaigne Bordeaux

118-2 | 2016

Varia

\title{
Realismo y realidad en Misericordia de Galdós
}

Juan Antonio Garrido Ardila

\section{(2) OpenEdition}

Journals

Edición electrónica

URL: http://journals.openedition.org/bulletinhispanique/4540

DOI: 10.4000/bulletinhispanique.4540

ISSN: 1775-3821

Editor

Presses universitaires de Bordeaux

\section{Edición impresa}

Fecha de publicación: 15 diciembre 2016

Paginación: 535-554

ISBN: 979-10-300-0125-9

ISSN: 0007-4640

Referencia electrónica

Juan Antonio Garrido Ardila, "Realismo y realidad en Misericordia de Galdós », Bulletin hispanique [En línea], 118-2 | 2016, Publicado el 15 diciembre 2019, consultado el 28 diciembre 2019. URL : http:// journals.openedition.org/bulletinhispanique/4540; DOI : 10.4000/bulletinhispanique.4540 


\title{
Realismo y realidad en Misericordia de Galdós
}

\author{
Juan Antonio Garrido Ardila \\ University of Malta
}

Misericordia (1897) de Galdós présente des traits propres au roman moderniste, comme la présence d'un narrateur peu fiable ou la déstructuration des séquences narratives. Cet article examine les techniques permettant à Galdós d'explorer la conception moderniste d'une réalité subjective et antipositiviste. Plus particulièrement, il s'agira de comprendre comment le monde réel et le monde imaginaire inter-agissent pour ne faire qu'un. Ainsi, Misericordia prélude au réalisme moderniste dont la réalité se fonde sur le rêve et l'illusion.

Mots-clés : Galdós, Misericordia, roman moderniste, réalisme.

Misericordia (1897) de Galdós contiene y atesora una serie de características propias de la novela modernista, como por ejemplo las tendencias infidentes del narrador y las alteraciones en las secuencias narrativas. Este artículo analiza los modos en que Galdós se adentra en la concepción modernista de la realidad subjetiva y antipositivista. Se analiza especialmente la correlación entre lo real y lo imaginado y cómo ambos planos se funden en uno. De esta suerte, Misericordia preludia el realismo modernista cuya realidad se fundamenta en la ensoñación.

Palabras claves: Galdós, Misericordia, novela modernista, realismo.

In Misericordia (1897), Galdós displayed some techniques characteristic of the modernist novel, such as the unreliable narrator, or deconstructing narrative structures. This article examines the means by which Galdós explored and presented reality in the subjective and anti-positivist manner of modernism. More precisely, it analyses the interplay between the real world and the idealised world as imagined by the characters, and how these two layers of reality become one. Misericordia thus prefigures modernist realism by forging a new literary form of a reality founded upon dream and illusion.

Keywords: Galdós, Misericordia, modernist novel, realism. 
$\mathrm{L}$ as novelas realista y naturalista se asoman al mundo desde la convicción absoluta y soberana de que la realidad es monolítica y constatable únicamente por medio de la fenomenología y el empirismo. Conforme la historia de la novela europea se aproxima al ocaso del siglo XIX, esa perspectiva se muda gradualmente para reconocer que la percepción cabal y entera de la realidad debe atender a fenómenos que, a veces, desafían a la ciencia. El realismo, con arreglo a cómo lo entendieron y asimilaron los novelistas realistas y naturalistas, apostata poco a poco de su credo empirista para encaminarse hacia una nueva forma de novela: la novela del modernismo. La novela modernista no surge por generación espontánea sino que adquiere cuerpo en un proceso que se remonta, así en España como en el resto de Europa, a los años 1889-1890. En España, el último decenio del Diecinueve trabará una sucesión de novelas que dieron pasos de gigante hacia la conformación de una suerte de realismo literario distante y desentendido del realismo naturalista (Gullón 2003 y Santiáñez 2002). Galdós es un autor clave en la progresiva transformación de la novela española desde el naturalismo hasta las formas modernistas de entre siglos, y sus últimas novelas adelantan elementos y técnicas propios del modernismo. Es, en definitiva, uno de los precursores de una suerte de realismo que contempla y reconoce una realidad subjetiva. Todo ello puede apreciarse nítidamente en novelas como, entre otras, La incógnita (1890) y Nazarín (1895). El presente trabajo se fijará en Misericordia (1897), obra en la cual se reconocen dos niveles de realidad -la realidad concreta y la realidad imaginada- que se entreveran para fundirse en uno. Aunque se la debe reconocer como novela escorada, en sus intenciones y sus técnicas, hacia el naturalismo, Misericordia augura y precede la novela modernista en la armónica coexistencia de lo real empírico y lo imaginado, que en el desenlace del relato se reconocen como verdades complementarias. (En este sentido, Misericordia debe tenerse como clara precursora de algunas novelas de Miguel de Unamuno y de otras de autores europeos como Knut Hamsun).

Los méritos que sitúan a Galdós en la vanguardia de la novela española se remontan a Fortunata y Jacinta. No obstante su fehaciente apostura de novela realista, Germán Gullón ha advertido en Fortunata y Jacinta elementos de interiorización propios de una incipiente estética modernista. Concluye Gullón al respecto que "Aunque sus formas novelescas se acercan a las modernistas, su conciencia del proceso artístico difiere en intensidad de la propiamente llamada modernista» (2003: 74). Ese acercamiento a las formas modernistas supuso, allá por la fecha de publicación de Fortunata y Jacinta, un avance sustantivo en materia novelesca. De La incógnita ha resaltado Nil Santiáñez su «radical modernismo» (2002: 96) merced a su presentación de una realidad desdoblada. Realidad presenta otro impulso en pos de la renovación de la novela, pues en ella pone Galdós en forma dialogada los hechos narrados en La incógnita, preludiando así novelas dialogadas como La casa de Aizgorri (1900) y Paradox, rex de Baroja (1906), además de la preponderancia del diálogo en obras unamunianas como Niebla (1914). La incógnita resulta ser una pieza axial en el proceder narrativo de Galdós, puesto que en ella ahondará asimismo en la 
interiorización descriptiva hasta ensayar conatos de monólogo interior que ya había esbozado en La desheredada (G. Gullón 2007: 9-47, 35-43; Garrido Ardila 2013). Este desdoblamiento de la realidad en una tendencia hacia la interiorización narrativa convierte a Galdós en uno de los primeros novelistas españoles en poner rumbo hacia la novela modernista.

Con Nazarín se interna Galdós en la esfera de lo onírico para reconocer los sueños como parte constituyente de la realidad (Álvarez 1993; López 1978; Schraibman 1960; Gillespie 1960; Gullón 1966). No fue ese el caso de sus anteriores novelas. En El amigo Manso, por ejemplo, se alude en varias ocasiones a los sueños $(174,261,282,283,363,373)$ para motejarlos siempre de fenómeno etéreo e ilusorio, ajeno a la realidad ${ }^{1}$. En cierta ocasión se les reconoce con sarcasmo su parte en el realismo calificándose súbitamente tal posibilidad de «tontería»: «Si el sueño es el reposo intermitente del pensamiento y de los órganos sensorios, ¡cómo pensé y vi...? ¡Pero qué tontería!» (283). Por el contrario, los sueños en Nazarín forman parte de una concepción del realismo que renuncia al empirismo y el racionalismo y transporta a los personajes a un nivel de existencia espiritual y superior a la realidad empírica. Por ejemplo, cuando Beatriz, en la venta camino de Villamantilla, no puede dormir y presiente males venideros, refiere el narrador que, por la mañana «vio cosas»:

para descansar más de dormir y con la conciencia de hallarse despierta, jvio cosas! Pero si antes veía cosas malas, ahora las veía buenas, aunque no pudo explicarse lo que era ni asegurarse de ver lo que veía. ¡Inaudita rareza! Y tenía que reprimirse para vencer el ciego impulso de abalanzarse hacia aquello que viendo estaba. ¿Era Dios, eran los ángeles, el alma de algún santo, o un purísimo espíritu que quería tomar forma sin poder conseguirlo? (246).

En las postrimerías del relato, sacan a Nazarín de la cárcel y lo conducen por las calles. Comienza el capítulo VI de la quinta parte: «Despertó con las ideas aun más embrolladas y oscuras, dudando si lo que veía era real o ficción en su mente» (344). Durante todo ese capítulo el narrador describe las visiones en que Nazarín se ve a sí mismo derrotando a un ejército del mal. Comienza el capítulo siguiente: «Acabóse la visión, y todo volvió a los términos de nebulosa y triste realidad» (349). Como en la experiencia de Beatriz, estas visiones, en que Nazarín se enfrenta valerosamente a un ejército hostil y sale victorioso de la empresa, bien pudieran entenderse como un trance del subconsciente, producto del cansancio de la mente, como un sueño. En el momento de la publicación de Nazarín, a mediados de los años noventa, este pasaje no puede dejar de entenderse, también, como un reconocimiento del poder del

1. Las referencias a las obras de Galdós y de Unamuno se indicarán en el cuerpo del texto y proceden de las siguientes ediciones: Benito Pérez Galdós, Nazarín, Madrid, Castalia, 2001; Benito Pérez Galdós, Misericordia, Madrid, Cátedra, 2011; Benito Pérez Galdós, El amigo Manso, Madrid, Cátedra, 2010; Miguel de Unamuno, Amor y pedagogía, Madrid, Espasa-Calpe, 2007; Miguel de Unamuno, Niebla, Madrid, Cátedra, 2005; Miguel de Unamuno, Nuevo mundo, Madrid, Trotta, 1994; Miguel de Unamuno, Paz en la guerra, Madrid, Cátedra, 1999. 
subconsciente. Aunque el narrador emplea estas imágenes lúdicamente y deja abierta la posibilidad de interpretaciones, el contexto y la naturaleza de estas visiones las hacen susceptibles de tenerse por ensoñación producida por el subconsciente.

Se trata, en definitiva, de una percepción de los sueños y de los estados de subconsciencia muy otra a la que hallamos en novelas anteriores como El amigo Manso. En Nazarín reconoce Galdós que el mundo interior de los personajes posee un valor para la realidad exterior. La batalla que el protagonista libra en sueños con esas huestes sigue a la persecución de que en los días anteriores ha sido objeto a manos de los protervos lugareños. En esta novela, los sueños complementan la realidad y son parte de ella. De este modo, se trasciende el realismo empirista propio de la novela realista decimonónica para reconocerse un realismo irracional.

Antes de Nazarin habían recurrido a estados de semiconsciencia tanto Pardo Bazán en Insolación (1889) como Clarín en Su único hijo (189o). Después de Nazarín escribiría Strindberg sus obras teatrales oníricas Til Damaskus (A Damasco) publicada en dos partes en 1898 y Ett Drömspill (Un drama onírico) escrito en 1901 y escenificado en $1907^{2}$. Las pesadillas juegan un papel determinante en la percepción que Johan Pilsen Nagel, el protagonista de Mysterier (1892, Misterios) de Hamsun, tiene de su existencia. En Nuevo mundo de Unamuno, obra acabada en 1896 y que permanecería inédita hasta 1994, afirma el narrador: «iGenerosos ensueños, a la luz de cuyo ideal inasequible hay que ver la miserable lucha en que vivimos!» (70). En Paz en la guerra, publicada en 1897, mismo año que Misericordia, expresa en una ocasión el narrador que el protagonista «no pocas veces despertaba en sueños [...] el Coco infantil que dormía en el fondo de su alma» (155) antes de apuntar que sońaba "despierto» (300) y que "Parecíale la guerra un cuento, y el mundo un sueño» (305). En torno a esa época, en 1899 (aunque con fecha de 1900) se publicaría Die Traumdeutung (La interpretación de los sueños) de Freud. En Amor y pedagogía (1902) de Unamuno, los sueños y otros estados de ensoñación constituyen un nivel de significación paralelo a la realidad empírica ${ }^{3}$. Proclama allí el narrador: «Espera al sueño y es su más dulce vivir el de esperarlo. El sueño es la fuente de la salud, porque es vivir sin saberlo. No sabe que tiene corazón quien le tenga sano, ni sabe que tiene estómago o hígado sino quien los tenga enfermos; no sabe que vive el que duerme. En el sueño nadie le enseña nada. ¡Pero no!, hasta el sueño, hasta el sueño viene con ensueños, con pedagogía. ¿Dónde estará uno a salvo?, ¿dónde habrá un sueño sin ensueños e inacabable? ¡Qué sueño el de la vida!» (120-121). En esta novela, así Apolodoro como su madre escapan por medio de la ensońación de la aciaga existencia que su padre les impone.

2. Sobre los sueños en estas obras de Strindberg véanse: Benston 1965 y Jarvi 1972, entre otros.

3. Sobre los sueños en Amor y pedagogía al modo freudiano y, posteriormente, en Niebla, véase Garrido Ardila 2012. 
En ese breve espacio de tiempo, de apenas unos doce años, que transcurre desde Su único hijo y Mysterier hasta las obras de Strindberg y Amor y pedagogía, los sueños se instauran como una parte esencial de la percepción total de la realidad y, por ende, en elemento axial del realismo literario ${ }^{4}$. En ese periodo se publica Misericordia, donde lo imaginado, lo soñado despierto que Unamuno reconoce después como parte integrante del realismo y la realidad, desempeña ya una función ancilar en la representación literaria de la realidad. Esta misma perspectiva adoptaría Knut Hamsun en Svermere (1904), donde el protagonista vive su vida ensimismado en un mundo imaginario 5 .

A pesar de su innovadora concepción del realismo, fundamentada en una realidad que rebasa lo empírico, Misericordia ha sido entendida como una obra de entronque fundamentalmente realista-naturalista, por razón de su incisión descriptiva en los personajes tipo, su empleo de los espacios físicos de Madrid y la conciencia omnisciente del narrador. Los estudios sobre esta obra son sin número; baste con recordar cómo Sádaba Alonso (2001-02) observaba el realismo de las descripciones y del uso de ciertos espacios físicos de la villa de Madrid que trasladan al lector un mensaje social, o los muchos críticos que han resaltado el tratamiento central del tema de la indigencia y la decadencia social, temas troncales en la literatura naturalista (Fuentes Peris 2002; Lissorgues 1997; Barr 1982; Mora García 1994). Efectivamente, activa Galdós en Misericordia sus magistrales dotes descriptivas, retratando con esmerado realismo a personajes como Frasquito, Almudena o Benina. Se acomete el problema social de los indigentes, la hipocresía de don Carlos, la tragedia de dońa Francisca con el objeto de denunciar, con énfasis naturalista, la insensibilización social ante el pauperismo callejero y la vergonzosa inaptitud de las clases medias. Pero siendo novela de vetas indubitablemente naturalistas, Misericordia adopta gallardamente ese nuevo realismo irracional y antipositivista que reconoce el valor de los sueños. Ello explica, por ejemplo, el repudio que Blasco Ibáñez expresase por esta obra al reseñarla (Chamberlain 1990), toda vez que no entendía ese brusco giro de veleta que había llevado a Galdós de un realismo empirista a reconocer en las ensońaciones diurnas una realidad paralela a la realidad tangible. En ese sentido ha escrito Yvan Lissorgues que "Misericordia es un acierto artístico que merece compaginarse, como hemos sugerido, con algunas de las novelas más espirituales de Tolstoi» (1997: 189). Galdós tiene plena consciencia de sus intenciones espiritualistas, hasta el punto de que, en el último capítulo de la novela, afirma el narrador sobre el coloquio entre Juliana y Benina: «El diálogo fue breve, y de mucha sustancia o miga psicológica» (317). Esa miga psicológica preńa y nutre los más de los diálogos de la obra.

4. Notorio es que la literatura española fue pionera en el uso de sueños, con La vida es sueño de Calderón y el episodio de la Cueva de Montesinos en el Quijote, que críticos como Cascardi (1984) han identificado como un sueño.

5. Las Obras escogidas de Hamsun publicadas por la Biblioteca de Premios Nobel de la editorial Aguilar (Madrid, 1965), traducía svarmere como soñadores. Los traductores ingleses han optado por traducir svarmere como dreamers. Existe en noruego una diferencia entre svarmer y drommer. El drømmer es un soñador que duerme; por el contrario, el svermer es quien sueña despierto. 
Se dan en Misericordia una serie de innovaciones, con respecto a obras anteriores de Galdós, que han llamado la atención de la crítica (García Lorenzo 2011; Marín Martínez 1980). En esta novela se acentúa la tendencia hacia el diálogo sobre la descripción, preponderando así los personajes sobre el medio: de ser observados (por el narrador), los personajes pasan a actuar y observar. Al contrario que en novelas anteriores, en Misericordia los personajes actúan y dialogan antes de que el narrador los describa. También en esta obra se prescinde de la encapsulación de la acción narrativa en capítulos: las acciones se prolongan más allá de un capítulo, y finalizan cuando media otro, lográndose de ese modo una presentación de la realidad más libre de las formas novelísticas tradicionales. Por ejemplo, en el capítulo IV arranca un diálogo entre Benina y Almudena, que se continúa en el $\mathrm{V}$, en el que finaliza el diálogo y se inicia una nueva acción: «Emprendieron su camino presuroso por la calle del Mesón de Paredes, hablando poco» (91). De igual suerte, en el capítulo X regresa Benina a la casa y entabla conversación con doña Francisca, conversación que se prolonga en el capítulo XI, donde finaliza el diálogo y se inicia la visita de Benina a don Carlos. Desde antiguo, la crítica ha advertido también el empleo omnipresente en Misericordia de los ensueños y de una realidad idealizada y ajena a la realidad concreta. Robert Ricard (1961: 52) advirtió el recurso de la realidad imaginada como sostén de la trama. Joaquín Casalduero observó cómo «En Misericordia nos vemos trasladados sin cesar de la zona de la realidad a la de la imaginación o al contrario [...] en seguida un personaje nos aleja de ese mundo real y nos transporta a un mundo soñado» (1970: 12). Por su parte, Gustavo Correa consideró la interrelación entre lo real tangible y lo imaginado para reconocer que «el entrecruzamiento de planos de la realidad soñada o inventada con los de la realidad concreta, y su fusión final con esta última constituye, así, la característica particular del mundo novelesco de Misericordia» (1967: 207).

Más recientemente, Carlos Longhurst ha presentado Misericordia como hito trascendental en las progresiones de la teoría de la novela de entre siglos, considerando que la interrelación realidad-ensońación propicia que «it is a work whose theme or content could easily have been qualified it for a Naturalist label, but whose treatment of such a theme simply precludes such a denomination» (1997: 17). Longhurst concluye que Misericordia acomete ya la relación entre la realidad y la imaginación característica de la novela modernista y, en consecuencia, presenta a Galdós como «an older writer who is adapting and evolving the Realist formula to break new ground» (1999: 17). En trabajos posteriores en torno a la evolución de la novela espańola desde el realismo al modernismo, Longhurst ha retornado a Misericordia para proclamar su papel como obra gozne sobre el que gira la estética novelística. Sugiere que «A novel such as Misericordia [...] eludes easy clasification, for if, on the one hand, it seems as if Galdós sets out to offer a Naturalist study of the indigente classes of Madrid, on the other he clearly ends up creating a study in fabulation» (2000b: 29). Y especifica: "Misericordia es un experimento en fabulación. Ello se nota en diversos aspectos: en el uso, aunque vacilante, del estilo indirecto libre; en 
el comportamiento altamente imaginativo de los personajes [...]; y en la forma en que $[\ldots]$ se refleja intranovelísticamente la preocupación con la relación arte-realidad tan típica del modernismo noventaiochista y del modernismo europeo» (2000a: 174).

Tan atañedera al realismo es la cuestión relativa a lo imaginado en Misericordia como resultan ser otros elementos de la narración. En Misericordia se va forjando paulatinamente una concepción del realismo literario resultante de entrelazar la realidad concreta y la realidad imaginada o sońada; al objeto de disminuir la presencia de la realidad empírica, Galdós se sirve asimismo del narrador. Aun cuando del narrador de esta novela se ha venido conviniendo su calidad de narrador omnisciente, algunos críticos han observado asimismo cómo Galdós determina sus intervenciones con la precisión del titiritero que maneja una marioneta. Germán Gullón reparó en que el narrador «unas veces aparece como testigo y otras se nos presenta como omnisciente» (1974: 173); esto es, que la voz narradora no siempre ostenta su visión omnisciente de la realidad, sino que a veces se convierte en ese "testigo", pasivo y desprovisto de juicio plenipotenciario. Se trata de un ajuste obrado por Galdós en su obra y que produce un efecto calibrado: «[el] narrador (el quién) y las técnicas narrativas (el cómo) permiten que un fenómeno aparentemente foráneo, ocurra y se ajuste a la estructura novelística sin violentar en nada el ambiente 'realista' creado por Galdós», puntualiza Gullón (1974: 171). La precisa y perfecta matemática artística del relato se naturaliza para lograr que lo fantástico desplace al narrador omnisciente sin restarle autoridad. Para ello recurre Galdós al sabio juicio del lector, como ha explicado Nicole Malaret:

Esta coherencia y esta lógica suponen para el autor estorbos que, a veces, siente tentaciones de desechar. Pero ahí está el lector para preservarlas, exigiendo no sólo detalles y precisiones sino también una verdad coherente. Tanto es así que el autor se siente cada vez más prisionero de los trazos iniciales de su relato, que no debe traicionar. Las exigencias que en un primer tiempo venían impuestas desde el exterior vienen a estarlo del interior: el personaje adquiere cada vez mayor consistencia y no se deja manipular fácilmente. El esquema inicial impone sus condiciones y no admite otra evolución que la que sea lógica e integre los elementos constitutivos del personaje (1982: 91-92).

De esta suerte, el narrador comparte su autoridad con los personajes y el lector. Es un narrador omnisciente que ha dejado de serlo y esto se percibe en un sinnúmero de instancias a lo largo del relato, como paso a analizar.

Este narrador proclama en los principios del relato que tiene en suertes relatar la "puntual historia» (96) de la vida de Benina. Con el relato muy avanzado, en el capítulo XXV, el narrador engola su discurso y afirma de sí mismo, en tercera persona: «Y el historiador debe hacer constar asimismo [...]» (218) para puntualizar en el párrafo siguiente que la información que nos da se debe a «fuentes fehacientes» (218). En el capítulo XXVII leemos: «Pasaron unas carretas de bueyes con carga de retama y carrasca para los hornos de Madrid y ya fuera que se espantase el jaco, ya que fingiera el espanto, ello es que empezó 
a dar botes y más botes» (293-294). El narrador no enjuicia el arranque del equino, pero nos precisa que la carga es retama y carrasca y que está destinada para los hornos de Madrid, sin que el carretero lo haya especificado. Se trata de la actitud propia de un narrador del realismo.

Pero a esas alturas de la narración, el lector se ha percatado de que las fuentes de información están muy a menudo lejos del alcance del narrador ${ }^{6}$. Ya en el capítulo II el narrador, transido de "fuentes fehacientes», refiere que se desconoce la razón del apodo de un personaje: «La que en el anterior coloquio pronunciara frases altaneras y descorteses tenía por nombre Flora y por apodo la Burlada, cuyo origen y sentido se ignora» (73). Es decir, que apenas transcurrido capítulo y medio, el narrador de esta novela de ambientes palmariamente naturalistas reconoce ignorar una razón clave para la descripción moral de un personaje. Luego de haber reconocido ignorancia en ese capítulo II, en el V el narrador confiesa sus limitaciones cognoscitivas: «El mendigo, en tanto, pronunciando palabras coléricas, que no es fácil al narrador reproducir, por ser en lengua arábiga [...]» (92). Será una de las escasas ocasiones en que Almudena, el mendigo árabe, se exprese en su lengua materna, y lo que el narrador pudiera fácilmente haber soslayado o parafraseado, le sirve de excusa para volver a reconocer que carece de toda la información. En ese mismo capítulo incide el narrador en su desconocimiento de las lenguas en que se expresa Almudena: «El ciego no le hacía más caso que a un perro, atento sólo a sus rezos en lengua que no sabemos si era arábiga o hebrea [...]» (94). Nuevamente, el narrador podría haberse limitado a indicar que Almudena rezaba, pues el contenido de los rezos carece, en principio, de relevancia para la historia; por el contrario, descubre, sin necesidad alguna, su ignorancia como narrador. Curiosamente, muchos capítulos después indica que el ciego recitaba «oraciones hebraicas» (240), y el lector habrá de desconfiar de que ahora sí reconozca esa lengua. Estos apuntes no son caprichosos: en una novela en que el realismo habrá de trascender lo empírico característico de la novela naturalista, Galdós está vistiendo a su narrador (en principio y apariencia) omnisciente con los hábitos del narrador no omnisciente propio de la literatura modernista.

A partir de aquí, las instancias en que el narrador reconoce ignorancia se alternan con alardes de omnisciencia. Cuando en el capítulo IX Benina miente a dońa Francisca, el narrador declara que las respuestas de la criada constituían un «simulacro perfecto de la verdad» (119). En el XII se permite interrumpir un diálogo para explicarlo: «La convicción profunda que Almudena mostraba hizo efecto en la infeliz mujer» (138). Por otra parte, en el capítulo XX indica que «Benina sacó de toda la campaña del día, comprendido funeral y boda, 22 céntimos, y Almudena, 17. De Casiana y Eliseo se dijo que habían sacado

6. Por otra parte debe adelantarse que esta puntualización del narrador en el capítulo XXV se debe a que el narrador se dispone a insertar una anagnórisis, de suerte que rompe la linealidad del relato y apunta hacia la narración fragmentada propia del modernismo. Esto es, que un elemento del realismo naturalista se pone al servicio de un recurso plenamente modernista cual es la diégesis fragmentada. 
peseta y media cada uno» (186). Ese «se dijo» connota una inseguridad en la información. Carece aquí el narrador de esas «fuentes fehacientes» y sugiere un dato en lugar de ratificarlo. En el capítulo XXIX apunta que lo que se dispone a explicar «Es cosa averiguada [...]» (242), pero antes de que acabe ese capítulo, y refiriendo cómo un grupo de gentes habían reparado en Benina y Almudena, escribe: «¿Qué decían? No era fácil entenderlo desde arriba. Palabras sueltas llegaban» (246). Aquí el narrador cede la perspectiva a los personajes: los protagonistas no aciertan a entender las palabras de aquellas gentes, y el narrador o bien carece de esa información o bien prescinde de ella. Pero, en cualquier caso, nos hallamos o bien ante un narrador que no es omnisciente, o bien ante un narrador omnisciente que prescinde de su omnisciencia. Ello constituye una singular toma de distancias con la novela realista-naturalista.

En el antepenúltimo capítulo de la obra, el narrador vuelve a dejar sentado que carece de datos fehacientes: «Pero ¿quién le había dicho las señas del nuevo domicilio? Sin duda fue Polidura el soplón y Juliana hizo juramento de arrancarle una oreja» (311). La información aquí no se debe a que el narrador la conozca, sino a la suposición de Juliana, que el narrador da por buena. Esto es, que el juicio del narrador queda desplazado por el juicio de un personaje. Otro tanto de lo mismo había acontecido ya en el capítulo X, que finaliza cuando doña Francisca enjuicia la moralidad de don Carlos:

¡Qué le importarán a ese corazón de piedra la madre ni los hijos! ¡Un hombre que tiene en Madrid treinta y cuatro casas, según dicen, tantas como la edad de Cristo y una más; un hombre que ha ganado dinerales haciendo contrabando de géneros, untando a los de la Aduana y engańando a medio mundo, venirse ahora con cariñitos! A buenas horas, mangas verdes... Le dirías que le desprecio, que estoy por demás orgullosa con mi miseria, si miseria es una barrera entre él y yo... Porque ese no se acerca a los pobres sino con su cuenta y razón. Cree que repartiendo limosnas de ochavo, y proporcionándose por poco precio las oraciones de los humildes, podrá engañar al de arriba y estafar la gloria eterna, o colarse en el cielo de contrabando, haciéndose pasar por lo que no es, como introducía el hilo de Escocia declarándolo percal de a real y medio la vara, con marchamos falsos, facturas falsas, certificados de origen falsos también... ¿¿Le has dicho eso? Di, ¿se lo has dicho? (126).

Paradójicamente, es doña Francisca -personaje que no acertará a descubrir las mentiras de Benina- quien revela toda la verdad sobre don Carlos, la verdad de su vida y la verdad de su falsa moralidad. El lector tiene ante sí a un personaje crédulo que presenta un atinado juicio por medio de lo cual desplaza al narrador, que se mantiene al margen. El caso posee una trascendencia superlativa en la historia de la novela espańola. Presenciamos a un narrador omnisciente que calla ante los juicios de un personaje que, por otro lado, no acierta a ver la realidad de las mentiras de Benina. Si el narrador conociese esa información, resultaría que la ha puesto en boca de un personaje de moralidad poluta (como se irá viendo en el relato). De ello se sigue: 1) que si fuese un narrador omnisciente se trata de un narrador que volitivamente se ha hecho narrador infidente, y 2) que si no fuese omnisciente su remisión a intervenir le descubre fácilmente como infidente. 
Lo cierto es que el narrador no es ya un narrador omnisciente a la guisa de las novelas naturalistas. La infidencia de su narración se pone de manifiesto en dos instancias: las referencias de Frasquito a sus habilidades como jinete, y los colores con que se adjetiva la mano de Almudena. Construyéndose un pasado imaginado en París para deleite de Obdulia, Frasquito reconoce en primera instancia: «Yo he sido regular jinete» (172). Avanzado el diálogo, y según Frasquito magnifica la idealización de sus recuerdos, asegura que de joven tuvo una hermosa jaca torda y que «la montaba y gobernaba admirablemente» (174) para afirmar poco después: «Pues sí, yo era un buen jinete, y créame, algo queda» (175). De confesarse un «regular jinete» pasa a declarar que montaba «admirablemente» y era un «buen jinete». Ante esta tergiversación de la realidad, el narrador calla y deja que el pasaje quede desprovisto del juicio moral típico de la novela realista.

Habrá de ser el mismo narrador quien peque de infidencia más adelante para despejar dudas sobre su papel. En el capítulo XXIV refiere el narrador la declaración amorosa de Almudena a Benina y precisa: «Al hacer la oferta de su blanca mano, acompañándola de un suspirar tierno y de remilgos de vergüenza [...]» (211). Empero, en el siguiente capítulo pinta a este mismo personaje «sentado, mudo, la negra mano extendida» (217). La mano que antes se calificó de blanca ahora es negra, y negra volverá a ser tres capítulos después, precisamente al volver a simbolizar el matrimonio: «no parecía él dispuesto a complacerla en extremo tan importante, mientras no le diese ella palabra formal de aceptar su negra mano» (240). Es claro que el narrador pinta la mano blanca poniéndose en la mente de Almudena (e incluso la de Benina) para reflejar la pureza del corazón y de las intenciones del enamorado (sutil modo de interiorización narrativa). Sin embargo, el empleo alternado de adjetivos opuestos se reviste de una gran significación: al pasar de ser «regular jinete» a «buen jinete», Frasquito crea un mundo imaginado en que se acomoda felizmente y muy a su solaz; al hacer de la "negra mano» de Almudena una "blanca mano» en el momento de la pedida, el narrador crea dos realidades distintas, ambas válidas a un tiempo. A estas dos instancias debe añadirse el momento en que el narrador refiere en cierta ocasión que Almudena pugnaba con una impertinente pulga "cuando... no es broma... se le aparecieron dos ángeles» (146). El narrador acentúa su carácter infidente: que en esta ocasión no bromee connota que en otras pudiera bromear, aunque un narrador omnisciente de la familia naturalista deberá, en efecto, de bromear cuando trae ángeles a su relato.

Ese perspectivismo dual se manifiesta ya desde la primera frase de la obra: «Dos caras, como algunas personas, tiene la parroquia de San Sebastián... mejor será decir la iglesia... dos caras que seguramente son más graciosas que bonitas: con la una mira a los barrios bajos, enfilados por la calle de Cañizares; con la otra al señorío mercantil de la Plaza del Ángel» (61-62). Germán Gullón (2003: 85) ha reparado en la perspectiva uniforme en novelas naturalistas como El escándalo (1975) de Alarcón y La Regenta (1884-1885). En las postrimerías de El escándalo se dice de un personaje que gustaba de contemplar la noche con un telescopio; en el primer capítulo de La Regenta se intima cómo Celedonio 
contemplaba con un anteojo a la regenta desde la torre de la iglesia. Explica Gullón el cambio obrado por Clarín en la perspectiva: el personaje contempla desde las alturas para descubrir la intimidad de la protagonista que está en la tierra. La primera frase de Misericordia se presta a comparaciones con el inicio de La Regenta: aquí el narrador describe un espacio relacionado con una iglesia y también aquí se plasma la perspectiva que habrá de guiar la narración. Si en La Regenta esa perspectiva era unidimensional, en Misericordia se establece una realidad ambigua: la parroquia y las personas tienen «dos caras» y la realidad debe modularse -es lo que caracteriza el género de novela que la crítica anglófona ha llamado la Janus-faced novel-. Sentada la premisa de que la realidad puede entenderse desde dos perspectivas diferentes y con un narrador infidente y carente de todos los datos, la historia de Misericordia cobra sentido. Sin ese tipo de narrador, la fusión de lo real concreto con lo imaginado se hubiese forzado y desnaturalizado.

El narrador endorsa, pues, la formación de un nuevo realismo conformado por la realidad empírica y una realidad imaginada. Sobre esta novedosa interrelación cabe convenir con Correa (citado supra) en que se crean esos dos mundos paralelos que se fundirán en las postrimerías del relato. Al venir precedida de una conjunción armónica entre ambas esferas de la realidad, esa fusión ocurre de modo limpio y natural para proclamar la enseñanza de esta novela: que la realidad imaginada posee igual rango existencial que la realidad empírica. La grandeza de Misericordia reside en cómo Galdós va urdiendo esa interrelación entre ambos mundos. Existen en Misericordia tres casos de mundos imaginados, cada uno de los cuales tiene un forjador de la realidad imaginada y un receptor de esta: Benina-Francisca, Almudena-Benina y Frasquito-Obdulia. Cada uno de estos tres casos difiere sutilmente de los otros y todos juntos conducen a la tesis final de la novela -que la realidad se compone de la realidad empírica y la realidad imaginada o soñada-. La historia de Benina se extiende durante toda la novela, de los capítulos IX al último (titulado «Final», que no está numerado pero que debiera ser el XLI), para alcanzar la antedicha conclusión; la de Almudena se extiende del capítulo XII al XXIX; la de Frasquito del capítulo XV al XVIII. Esto es, que el desarrollo de los mundos imaginados se estructura conforme a una disposición de mise en abyme: la historia de Frasquito (capítulos XV al XVIII) se contiene en el espacio en que transcurre la de Almudena (XII al XXIX) y esta en el espacio de la de Benina (IX al «Final»). Los ensueños de Frasquito y Obdulia no habrán de materializarse (se trata del pasado y el mismo Frasquito fallece después de relatarlo); los de Almudena cobrarán sentido al racionalizarlos Benina ${ }^{7}$; y los de Benina se convertirán en realidad. De este modo, las historias, en progresión desde lo verdaderamente imposible (Frasquito) hasta lo posible (Almudena)

7. Recuérdese que Benina da largas a Almudena y que cuando este vuelve a preguntarle por Frasquito ella le cuenta una mentira: «Tragóse el africano esta bola con infantil candor» (241) indica el narrador. Disipada la amenaza del competidor, Almudena ceja en sus maravillosas ensońaciones. 
y lo realizable (Benina) pergeñan la tesis de la novela: los sueños dan ilusión a la vida y esa realidad soñada puede volverse realidad concreta. Se da en la obra una progresión en lo referente a la concreción de lo imaginado y su asentamiento en la realidad concreta. La historia de Frasquito está narrada en pasado y será realidad solo en la imaginación de Frasquito y de Obdulia. La historia de Almudena se resolverá en su interior pero no adquirirá rango de realidad concreta ni en Benina ni en nadie más. La historia de Benina, por el contrario, se resolverá con la materialización de lo imaginado en la realidad. Todo ello llevará a las conclusiones del relato: que la realidad se sitúa en la «vaga fluctuación entre lo real y lo imaginado" (204) y que "todo lo que sońamos tiene existencia propia» (253), por lo que el ser humano debe experimentar las ilusiones del mundo imaginado, además de que lo imaginado bien puede convertirse en realidad tangible. Veamos, pues, cómo se desarrollan cada una de estas historias en el concierto general de la obra.

Casada Obdulia (la hija de doña Francisca), Frasquito se aficiona a visitarla atraído por las comidas de la casa. La boda ha permitido a Obdulia subsistir económicamente, aunque sin excesos, pero no deja ella de añorar los tiempos de abundancia. Percibido de ello, Frasquito hace sus visitas agradables relatándole su pasado en la alta sociedad. Refiere el narrador que en cierta ocasión "platicaban gozosos de cosas gratas, harto distantes de la triste realidad" (156). Indica entonces que ambos poseían una «riqueza inagotable» (157, cursivas en el original) consistente en «la facultad preciosa de desprenderse de la realidad, cuando querían, trasladándose a un mundo imaginario, todo bienandanzas, placeres y dichas. Gracias a esta divina facultad, se daba el caso de que ni siquiera advirtiesen, en muchas ocasiones, sus enormes desdichas [...]» (157). El narrador dedica la mejor parte de esos cuatro capítulos a presentar las fantasías de Frasquito y el efecto catártico que obran en Obdulia -a más de insertar, en analepsis, la historia de él y de cómo llegó a frecuentar la casa de ella-. Frasquito refiere a Obdulia las noticias antiquísimas de la alta sociedad de otrora, almibaradas con revestimiento de poesía. Al hablarle de París, la imaginación de Frasquito levanta el vuelo edificando castillos en el aire. Obdulia le confiesa que al leer novelas se identifica con las heroínas y le descubre uno de sus sueños: "Yo sueño con tener un magnífico jardín y una estufa... iAy! Esas estufas con plantas tropicales y flores rarísimas, quisiera verlas yo» (170).

Así, Galdós nos ha presentado a dos personajes que imaginan un mundo idílico que anhelan. Esos sueños de vida despreocupada y suntuosa se imponen a la realidad concreta y la desplazan de los momentos de intimidad, forjando unos deseos que condicionan la experiencia del vivir. El mismo Frasquito confiesa que de hito en hito recorre las "calles sońando despierto" (173) absorto en ideales inalcanzables. Hablando del recuerdo de la emperatriz Eugenia, afirma: «en mi espíritu vive la imagen de aquella mujer» (173). Cuando Obdulia apunta que Frasquito a buen seguro fue un gallardo jinete y este se comide en su respuesta, ella afirma: «¿Por qué es usted tan modesto? Yo lo veo así, y suelo ver las cosas bien claras. Todo lo que yo veo es verdad» (175). 
Obdulia convierte así la mentira en «verdad». La conversación sobre el pasado parisino de Frasquito acaba cuando en «el punto o vértice del delirio hízoles caer de bruces sobre la realidad la brusca entrada de Benina» (176).

Los sueños de Frasquito y Obdulia no se materializarán: él fallece y la herencia no permitirá a Obdulia comprarse un jardín y un invernadero con flora exótica. Pero, en definitiva, tanto Frasquito como Obdulia reconocen una realidad idealizada moralmente superior a la realidad concreta y distinguen meridianamente dos vidas: la vida real y la vida del «espíritu». Lo que Obdulia ve en ensueños, en su espíritu, constituye, como ella afirma, la «verdad» (supra). Ello se constata avanzada la narración, cuando Frasquito dilapida sus exiguos dineros comprando un retrato de la Emperatriz Eugenia, con el propósito de mostrar a Obdulia el gran parecido entre ella y la emperatriz: Benina no percibe parecido alguno, pero Frasquito insiste erre que erre en que «son idénticas... La una como la otra, ésta como aquélla» (196). Se trata de la misma tesis que Hamsun desarrolló después en Svarmere: las ilusiones y la ensońación se constituyen en una verdad de igual o mayor rango que la realidad concreta. $\mathrm{Y}$ Galdós va más allá, pues al pintarnos a Obdulia anhelando ser una heroína de novela, se adelanta a Niebla de Unamuno, en que la literatura y la realidad se equiparan.

El lector conoce las fantasías de Almudena en el capítulo XII, cuando este revela misteriosamente a Benina que ella podría hacerse, si así lo quisiere, de todas las riquezas de don Carlos, por medio de un embrujo. A partir de entonces, el ciego revela cómo un ente deífico llamado Samdai se le aparecía para dictarle su destino vital (137). Apunta el narrador que Benina se presta a escuchar a Almudena porque siempre fue propensa a acreditar en toda suerte de «historias sobrenaturales» (137). Dos géneros de historia sobrenatural relatará Almudena: los embrujos y su visión profética. El hechizo por medio del cual Benina pudiera hacerse rica precisa de tal cantidad de requisitorias que la misma Benina desistirá de ello, y los lectores habrán, a buen seguro, de sonreírse ante las ocurrencias de Almudena. De otra parte, la visión guiará la vida del pobre ciego hasta darle sentido.

Relata Almudena que en cierta ocasión tuvo una «espléndida visión» (148) en que Samdai le presentó riquezas en cantidad y valor incalculables. Como quiera que el mayor anhelo de Almudena residía en disfrutar del amor de una mujer, Samdai hubo de precisarle que solo podría obtener uno de los dos deseos: o riquezas o mujer. A ello repuso el ciego que prefería una mujer. Entonces le señaló Samdai la imagen de una dama, que caminaba embozada en un hábito que le ocultaba las facciones. La profética imagen sirve a Almudena para explicar su pasado y reclamar que, luego de haber encontrado a una mujer que no era la escogida, reconoció a Benina como la dama prometida.

El narrador establece de súbito un contraste agreste entre la realidad imaginada de Almudena y la realidad concreta, cuando Petra da su versión de esa misma realidad: «Y en Valencia encontraste a la Nicolasa, con quien veniste por badajes, que vos daban los aiuntamientos, con dos riales de tapa [...] y de Madrid vos fuisteis a los Portugales, y tres años te duró el contento, camastrón, 
hasta que la golfa se te fue con otro» (150). A ello repone Almudena: «Tú no saber» (150). La soberbia respuesta del ciego vindica a maravilla el valor de las ensońaciones: la realidad que a Petra parece banal -el viaje y el desengaño con Nicolasa-, para el ciego justifica su existencia y la ilusión de cumplir su destino filográfico.

Galdós nos presenta, pues, dos tipos de personas: quienes se aferran a la realidad concreta y en ella habrán de quedarse porque no aspiran a otra, y quienes sueñan ilusiones de una vida idealizada. El lector habrá de sospechar que el ciego ha inventado todo aquello conscientemente para conquistar a Benina. En cualquier caso, en Almudena tenemos otro ejemplo de personaje que vive en un mundo imaginado y que aspira a que ese mundo ideal se imponga al real. No será hasta el capítulo XXIV cuando Almudena confiese a Benina que en ella ha reconocido a la mujer que Samdai le señaló. Galdós nos presenta entonces a un personaje cuyos sueños se hacen realidad, pues aunque Benina no acceda al matrimonio, ella confiere sentido a la vida del ciego. En esta historia hallamos, pues, al soñador que cree en sus sueños, sueños esos que, no obstante, no convencen a Benina.

En Benina-Francisca se presenta un caso antípoda: Benina construye un mundo en que, al principio, no cree, pero que adquiere rango de realidad en doña Francisca. La historia de Benina y de cómo su realidad imaginada se concreta centra la trama de la obra. En el transcurso del relato esa realidad imaginada se va materializando gradualmente. En los primeros capítulos, el narrador se referirá a esa realidad como «mentiras» (98), "piadosos engaños» (119) y «embuste[s]» (125). De esta suerte, Galdós -con acento naturalistanos convence en un primer momento de que esa realidad forjada en la fantasía solo merece calificarse por medio de esos sustantivos casi peyorativos. Sin embargo, conforme avanza la narración, esa realidad cobrará vida en la mente de doña Francisca, y cuando el verdadero sacerdote don Romualdo entra en escena, la misma Benina habrá de convencerse de que lo que fue imaginado se ha convertido en realidad. $\mathrm{O}$, para ser más precisos, que el ensueño tenía un paralelo en la realidad concreta. Pero, a efectos de la historia, lo imaginado por Benina (i.e., don Romualdo) y lo deseado en sueños por dońa Francisca (la herencia) habrá de tornarse en realidad. Cuando Benina logra salir del hogar de indigentes y determina "Cuando vuelva a casa diré la verdad» (256) no tiene aún conciencia de que la mentira se ha hecho verdad y de que la verdad en ese momento es lo que antes fue mentira. El proceso de concreción de lo imaginado se demora durante toda la obra y constituye el objeto de la trama. En su transcurso, se reclama en progresión la equivalencia entre el mundo concreto y el mundo imaginado, a veces por medio de apotegmas puestos en boca de los personajes. De especial interés resulta el empleo que Galdós hace de estados oníricos: al soñar despierto añade el soñar nocturno de doña Francisca. Así, Galdós implícitamente reconoce que el mundo onírico contiene los deseos de las personas, y esas tres dimensiones -lo imaginado conscientemente, lo soñado oníricamente y la realidad concreta- se hacen una. 
El narrador explica en el capítulo IX cómo Benina inventó a don Romualdo, a quien dice servir como asistenta para justificar ante dońa Francisca sus ausencias y el dinero que en realidad recibe mendigando. Indica el narrador que todos los detalles referentes a don Romualdo -su bondad, su fama como clérigo y su inminente nombramiento como obispo- los forja Benina «en su mente» (121) o por medio de "preparación mental» (129). La misma Benina tiene plena conciencia de que lo que dice a doña Francisca son «mentiras» (135). Se establece, pues, que la realidad que Benina presenta a dońa Francisca (esto es, que sirve a don Romualdo y que ambas viven del sueldo) es pura mentira. De ello tiene plena conciencia Benina; sin embargo, cuando Almudena le explica el conjuro, ella se esfuerza en creer y se justifica: «lo que una sueña ¿qué es? Pues cosas verdaderas de otro mundo que se vienen a éste... Todo puede ser, todo puede ser» (140). Esta teoría de los sueños la refuerza el narrador al reflexionar: «¿Y no puede suceder que alguno sepa lo que no sabemos los demás?... ¿Pues cuántas cosas se tuvieron por mentira y luego salieron verdades? Antes de que inventaran el telégrafo, ¿quién hubiera creído que se hablaría con las Américas del Nuevo Mundo, como hablamos de balcón a balcón con el vecino de enfrente? [...] Hay misterios, secretos que no se entienden, hasta que viene uno y dice tal cual, y lo descubre» (141). A partir de entonces, la narración se centrará en la historia de Almudena y Samdai y en las ensoñaciones de Frasquito y Obdulia. Sentada así la teoría de que la realidad imaginada se impone a la realidad concreta, la historia de Benina discurrirá después, intensificando la relación entre las mentiras y la realidad, hasta fundirlas en una.

Inmediatamente después de la conclusión de los relatos parisinos de Frasquito, se relata el episodio en que dońa Francisca mezcla la verdad con la mentira (178-179): Francisca cree que en lugar de acudir a casa del sacerdote, Benina va a ver a Obdulia. La mentira sobre don Romualdo se ha convertido en verdad, y la verdad de las visitas a Obdulia se ha convertido en mentira. De esta suerte, la realidad se ha invertido y lo imaginado se ha tornado realidad para doña Francisca. En ese mismo capítulo continúan conversando y, curiosamente, la señora -que ha creído a pies juntillas la historia de don Romualdo- proclama que ella conoce la realidad de la conversación entre Benina y don Carlos. Cree lo falso referente al sacerdote, pero no quiere creer la verdad de la entrevista entre Benina y don Carlos, de modo que la verdad queda desplazada por el ensueńo. Se interesa entonces por la cantidad de dinero que su criada ha recibido en limosna de don Carlos, en lo que dońa Francisca vuelve a invertir las categorías de la realidad. Ante las cifras supuestas por la señora, Benina le reprocha que esté delirando, a lo que acota el narrador: «replicó [...] plantándose con firmeza en la realidad" (181). En cualquier caso, en este episodio se han entreverado la mentira con la realidad y, sobre todo, se ha demostrado que la mentira de don Romualdo ha arraigado en dońa Francisca para convertirse en realidad. Además de ello, doña Francisca expresa que «si son verdad los milagros, ¿por qué no sucede uno para nosotras, que bien merecido nos lo tenemos?» (183).

Con la mentira convertida en realidad para dońa Francisca y con las teorías de las mentiras adelantada por Benina y la de los milagros por su señora, en el 
siguiente capítulo Benina considera la posibilidad de que las mentiras puedan convertirse en verdades y se decide a ensayar el sortilegio de Almudena guiada por una contundente corazonada: «iCuántas mentiras hubo que se volvieron verdades como puños!» (184). Dos párrafos después, el narrador explica que Benina iba «pensando por el camino en D. Romualdo y su familia, pues de tanto hablar de aquellos señores, y de tanto comentarlos y describirlos, había llegado a creer en su existencia» (184). Es este el momento en que, luego de todos los antecedentes y consideraciones, Benina comienza a acreditar en sus fantasías y estas asoman a la realidad concreta.

Asentada y establecida la mentira en la realidad, Galdós añade al relato una dimensión onírica. Cuando Benina lleva a Frasquito enfermo a casa de su señora, esta «al ver cosa tan extraña creía soñar» (198). Galdós reconoce aquí que el sońar constituye una realidad extraña, y equipara la realidad concreta a la onírica. Dicho de otro modo: reconoce que los sueños pueden asemejarse a la realidad y viceversa. La cuestión de la realidad onírica se desarrolla en las páginas siguientes, cuando doña Francisca sueña que se le presentan unos testamentarios para comunicarle que ha recibido una pingüe herencia que le devolverá a su vida suntuosa. El sueño parece tan real que, cuando lo relata a Benina, esta le pregunta: «pero dígame: ¡es sońado lo que me cuenta o es verdad?» (200). Cuando dońa Francisca explica que se trata de un sueño y que los enviados la hallaron porque don Romualdo les facilitó sus señas, Benina exclama: «Pero vamos a cuentas: todo eso es, como quien dice, soñado» (200). Doña Francisca defiende entonces el valor de los sueños y Benina lo ratifica: «Los sueños, los sueños, digan lo que quieran [...] son también de Dios; ¿̇y quién va a saber lo que es verdad y lo que es mentira?» (201). Al volver a hablar del sueño de los testamentarios, Benina recuerda que aquello fue sońado y Francisca apunta que similar situación pudiera darse en la realidad. Momentos después une el narrador la realidad con los sueños: los personajes escuchan ruidos antes de dormirse, y el narrador señala que una vez cayeron dormidas siguieron escuchándolos en sueńos (224). En el siguiente capítulo, dońa Francisca informa a Benina que don Romualdo la ha visitado. En la entrevista entre la señora y el sacerdote, en el capítulo XXXIII, se une magistralmente lo imaginado con la realidad concreta, fundiéndose ambos niveles con naturalidad armónica ${ }^{8}$. Benina entiende que habrá de ser otro Romualdo, pero, a partir de entonces, lo que puede entenderse como una casualidad constatará la posibilidad de la conversión de lo imaginado en realidad. El sueño de Francisca sobre la herencia se hará realidad y así también el personaje creado por Benina. Como explica el narrador: «Ya tenía Benina un espantoso lío en la cabeza con aquel dichoso clérigo, tan semejante, por las señas y el nombre, al suyo; y pensaba si, por milagro de Dios, habría tomado cuerpo y alma de persona

8. Curiosamente, Galdós hace que Francisca y Benina recurran a una chiquilla que les corrobore que el episodio aconteció, como después en Niebla, después de que Augusto pida a Liduvina que le confirme que Mauricio lo ha visitado, Augusto sugiere que recurran a Domingo para que lo constate (264). 
verídica el ser creado en su fantasía por un mentir inocente» (251). El milagro que anhelaba dońa Francisca se ha tornado realidad. Cuando Benina regresa de su encierro en el hogar de indigentes y determina decir «la verdad» (256) esa verdad es ya lo que antes fue mentira. En ello se insistirá en varias ocasiones: «de los senos oscuros de la invención salía persona de verdad» (295) explica el narrador; «el milagro es una verdad» (297) revela Francisca a Benina; «Inventa [una] unas cosas que luego salen verdad, o las verdades, antes de ser verdades, han sido mentiras muy gordas» (317) barrunta Benina.

Galdós ha convertido, de un modo verídico, el sueño de doña Francisca y lo imaginado por Benina en realidad: el sueño de la señora muy seguramente tomó forma a partir de un presentimiento basado en el hecho fehaciente de que tenía familiares que podrían dejarle una enjundiosa herencia, lo cual dotó de sentido la casualidad de que el sacerdote real tuviese el mismo nombre que el imaginado por Benina. De cualquier modo, la fuerza de los deseos forjados en la imaginación o incluso en estados oníricos adquiere una fuerza que los transfiere a la realidad concreta. En el desenlace de la trama se cumple el principio que se apuntó en la primera frase: la iglesia, que es una, tiene dos caras, como las dos caras de la realidad (lo concreto y lo imaginado) hacen una única realidad. El desenlace de la obra redunda sobre eso mismo: obcecada por la presencia de la muerte, Juliana acude a Benina para rogarle unas palabras de consuelo que la tranquilicen. La palabra de Benina se toma como realidad, esto es, convierte los deseos y las ensoñaciones en realidad?

De esta suerte, Galdós impone en la novela espańola un nuevo tipo de realismo que trasciende el realismo empirista de la novela realista-naturalista. Los estados oníricos y las ilusiones se equiparan en valor existencial a la realidad concreta, con la posibilidad de convertirse en esa misma realidad concreta. Se trata de un avance sustantivo en la concepción del realismo literario que antecede a Amor y pedagogía y Niebla en Espańa y Til Damaskus y Svarmere en Escandinavia. Ello lo borda Galdós por medio de su estructura en mise en abyme y por la gradual transfiguración de lo imaginado en realidad concreta. Este realismo se materializa mediante los estados oníricos, las fantasías, el narrador infidente además de merced a una tendencia a la interiorización y una fragmentación de la diégesis por medio de la analepsis ${ }^{10}$. En su conjunto, Misericordia se configura como una novela lastrada en el naturalismo pero que apunta decididamente hacia el realismo antipositivista propio de la novela modernista.

9. Lo cual tiene un paralelismo con la fe: si en la Biblia el verbo se hizo carne, Benina hace del verbo realidad.

10. El espacio de este artículo impide un tratamiento crítico de la interiorización. Véanse los pasajes en que personajes se hablan a sí mismos (v.g., 67, 133, 208-209). 


\section{Bibliografía}

Álvarez Guzmán, «Nazarín, sus dos mujeres y un sueño», Actas del IV Congreso de Estudios Galdosianos, Las Palmas de Gran Canaria, Cabildo Insular, 1993, p. 31-39.

Barr Lois Baer, «Social Decay and Desintegration in Misericordia.» Anales Galdosianos, $\mathrm{n}^{\circ} 17,1982$, p. 97-103.

Benston Alice, «From Naturalism to the Dream Play», Modern Drama, 7, n ${ }^{\circ} 4,1965$, p. 382-398.

Cascardi Anthony J., "Cervantes and Descartes on the Dream Argument», Cervantes: Bulletin of the Cervantes Society of America, 4, n ${ }^{\circ} 2,1984$, p. 109-122.

Casalduero Joaquín, Vida y obra de Galdós (1842-1920), Madrid, Gredos, 1970.

Chamberlain Vernon A., «Blasco Ibánez’s Mistaken Evaluation of Misericordia», Romance Quarterly, 37, n 2, 1990, p. 209-215.

Correa Gustavo, Realidad, ficción y simbolo en las novelas de Pérez Galdós, Bogotá, Instituto Caro y Cuervo, 1967.

Fuentes Peris Teresa, «A Deseased Morality: Begging and Indiscriminate Charity in Galdós's Misericordia», Journal of Iberian and Latin American Studies, 8, n 2, 2002, p. 109-126.

García Lorenzo Luciano, Misericordia de Galdós, Madrid, SGEL, 1975.

— «Introducción», en Benito Pérez Galdós, Misericordia, Madrid, Cátedra, 2011, p. 11-58.

Garrido Ardila J. A., «El monólogo interior en la novelas espiritualistas de Pardo Bazán, Clarín y Galdós (1889-1895)", Boletín de la Real Academia Española, 93, no 309, 2013, p. 221-245.

- «Unamuno, Freud y Strindberg: los sueños en Amor y pedagogía y Niebla», Neophilologus, 96, $\mathrm{n}^{\circ}$ 1, 2012, p. 47-64.

Gillespie Gerald, «Dreams and Galdós», Anales Galdosianos, 1, 1966, p. 107-115.

Gullón Germán, "Misericordia: un milagro realista», Letras de Deusto, n 8, 1974, p. $171-185$.

— «Introducción», en Benito Pérez Galdós, La desheredada, Madrid, Cátedra, 2007, p. 9-47.

- El jardin interior de la burguesía. La novela moderna en España (1885-1902), Madrid, Biblioteca Nueva, 2003.

Gullón Ricardo, Galdós, novelista moderno, Madrid, Gredos, 1966, p. 167-217.

Hamsun Knut, Obras escogidas, 2 vols, Madrid, Aguilar, 1965.

Jarvi Raymond, «Ett Drömspel: A Symphony for the Stage», Scandinavian Studies, 44, $\mathrm{n}^{\circ} 1,1972$, p. 28-42.

Lissorgues, Yvan. «Benito Pérez Galdós: la novela tendenciosa de fin de siglo (Realidad, Angel Guerra, Nazarin Halma, Misericordia, El abuelo)", Camins Creuats, n² 2, 1997, p. 176-193.

Longhurst A. C., «The Turn of the Novel in Spain. From Realism to Modernism in Spanish Fiction», en Anthony Clark (ed.), A Further Range. Studies in Spanish 
Literature from Galdós to Unamuno, Exeter, Exeter University Press, 1999, p. 1-43.

— «Noventaiocho y novela: lo viejo y lo nuevo», en Joseph Harrison y Alan Hoyle (eds.), Spain's 1898 Crisis. Regeneracionism, Modernism, Post-colonialism, Manchester: Manchester University Press, 2000a, p. 170-180.

— «Ruptures and Continuities: From Realism to Modernism and the Avant-Garde», en Frank Lough (ed.), Hacia la novela nueva. Essays on the Spanish Avant-Garde Novel, Nueva York, Peter Lang, 2000b, p. 19-42.

López Mariano, «Antinaturalismo y humanismo en Galdós: Ángel Guerra, Nazarín y Halma", Hispania, n 61, 1978, p. 69-77.

Malaret Nicole, "Misericordia: una reflexión sobre la creación novelesca», Anales Galdosianos, $\mathrm{n}^{\circ} 17,1982$, p. 89-95.

Marín Martínez Juan María, «Aproximación a Misericordia. Análisis de tres constantes galdosianas», Revista de Literatura, n 42, 1980, p. 63-91.

Mora García, José Luis, "Misericordia en la España de Galdós», en Juana Sánchez-Gey (ed.), Filosofía y literatura, Madrid, Fundación Fernando Rielo, 1994, p. 53-79.

Pérez Galdós Benito, Nazarín, Madrid, Castalia, 2001.

- Misericordia, Madrid, Cátedra, 2011.

- El amigo Manso, Madrid, Cátedra, 2010.

Ricard Robert, Galdós et ses romans, París, Institute d'Études Hispaniques, 1961.

Sádaba Alonso Soraya, "Espacio y personajes en Misericordia de Benito Pérez Galdós», Cuadernos de Investigación Filológica, n 27-28, 2001-02, p. 63-80.

Santiánez Nil, «Poéticas del modernismo. Espíritu lúdico y juegos de lenguaje en $\mathrm{La}$ incógnita 1889", Modern Language Notes, 111, n² 2, 1996, p. 299-326.

- Investigaciones literarias. Modernidad, historia de la literatura y modernismos, Barcelona, Crítica, 2002.

Santiánez-Tió Nil, Ángel Ganivet, escritor modernista. Teoría y novela en el fin de siglo español, Madrid, Gredos, 1994.

Schraibman Joseph, Dreams in the Novels of Galdós, Nueva York, Hispanic Institute, 1960.

Unamuno Miguel de, Amor y pedagogía, Madrid, Espasa-Calpe, 2007.

- Niebla, Madrid, Cátedra, 2005.

- Nuevo mundo, Madrid, Trotta, 1994.

- Paz en la guerra, Madrid, Cátedra, 1999. 
